Tersedia online di

http://ojs.unik-kediri.ac.id/index.php/ekonika

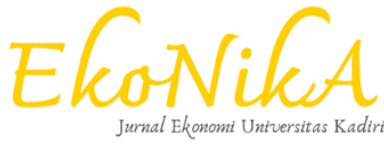

http://dx.doi.org/10.30737/ekonika.v5i1.847

\title{
ANALISIS KEPUTUSAN INVESTASI, KEPUTUSAN PENDANAAN, DAN KEBIJAKAN DIVIDEN TERHADAP NILAI PERUSAHAAN
}

INDEKS LQ-45

Moh. Zaki Kurniawan

Fakultas Ekonomi Dan Bisnis Universitas Trunojoyo Madura

email: zaki.kurniawan@trunojoyo.ac.id

\section{Artikel History:}

Artikel masuk : 03-03-2020

Artikel revisi : 16-03-2020

Artikel diterima : 14-04-2020

\section{Keywords:}

Keputusan Investasi (PER)

Keputusan Pendanaan (DER)

Kebijakan Dividen $(D P R)$

Nilai Perusahaan $(P B V)$

\section{ABSTRAK}

Studi tentang keputusan investasi, keputusan pendanaan, dan kebijakan dividen ini bertujuan untuk melihat pengaruhnya terhadap nilai perusahaan Indeks LQ-45 periode Februari 2017Februari 2019. Penelitian berjenis ex post facto dengan pendekatan kuantitatif yang menggunkan populasi 225 perusahaan dan dengan purposive sampling didapatkan 29 perusahaan.

Uji hipotesis menunjukkan hasil terdapat pengaruh keputusan investasi terhadap nilai perusahaan. Keputusan pendanaan dan kebijakan dividen tidak meliki pengaruh terhadap terhadap nilai perusahaan. Secara bersama-sama variabel independen tersebut berpengaruh terhadap variabel dependen.

\section{ABSTRACT}

This research on investment decisions, funding decisions, and dividend policy aims to see its effect on the company value of the LQ-45 Index for the period February 2017-February 2019. This type of ex post facto quantitative research approach uses a population of 225 companies and with purposive sampling found 29 companies.

Hypothesis test results show that investment decisions have a significant effect on firm value. Funding decisions and dividend policies do not significantly influence the value of the company. Together these independent variables have a significant effect on the dependent variable.

\section{PENDAHULUAN}

Investasi yang dilakukan perusahaan bertujuan untuk mendapat keuntungan dalam jangka panjang, sehingga keputusan yang diambil harus mempertimbangkan faktor resiko. 
Pengambilan keputusan investasi yang cermat oleh perusahaan akan mampu menaikkan aset dari perusahaan yang dimiliki dan akan berdampak pada kinerja perusahaan yang optimal. Adanya sinyal positif yang diterima oleh investor dari kinerja perusahaan yang optimal akan berdampak pada meningkatnya harga saham dan naiknya nilai perusahaan.

Manajemen keuangan perusahaan bertujuan untuk memaksimumkan nilai dari perusahaan. Manajemen keuangan mempunyai tugas melakukan pemilihan keputusan keuangan perusahaan seperti investasi, pendanaan, dan kebijakan deviden. Kombinasi yang proporsional dari ketiga hal tersebut akan menghasilkan penilaian perusahan yang optimal sehingga investor akan tertarik berinvestasi saham di perusahaan tersebut. Pemilihan struktur modal yang tepat akan menentukan sumber dana yang sesuai untuk sebuah perusahahaan. Ketersediaan dana atau modal perusahaan yang berasal dari sumber internal maupun eksternal akan mempengaruhi keputusan pendanaan perusahaan. Pengelolaan sumber dana internal dan eksternal harus tepat dan berimbang, sehingga laba yang diperoleh perusahaan bisa sesuai dengan target yang telah diharapkan. Beberapa penelitian terdahulu yang menunjukkan pentingnya pengaruh keputusan pendanaan terhadap nilai perusahaan telah banyak dilakukan (Nelwan dan Tulung, 2018; Alza dan Utama, 2018; Putra, Hidayati, dan Junaidi, 2018; Septariani, 2017; Muharti dan Anita, 2017; Cahyono dan Setyawati, 2017).

Kebijakan dividen menjadi salah satu problematika yang sering terjadi pada perusahaan, selain problematika keputusan investasi dan pendanaan. Dividen menjadi alasan investor ketika menanamkan investasinya. Para investor memiliki tujuan utama dari deviden, yakni meningkatkan kesejahteraannya dengan mengharapkan dividen dari suatu perusahaan, sedangkan perusahaan mengharapkan pertumbuhan perusahaan secara berkelanjutan sekaligus memberikan kesejahteraan berupa dividen kepada pemegang saham. Kebijakan dividen memiliki pengaruh tersendiri pada suatu perusahaan, karena menyangkut pembagian laba usaha atas investasi yang di tanamkan pada perusahaan, pembagian dividen yang tinggi dan sesuai harapan, sesungguhnya mampu menaikan nilai perusahaan. Kebijakan dividen yang benar mampu menjembatani antara keinginan pihak pemegang saham dengan pihak perusahaan dan bisa menghasilkan keputusan yang menguntungkan, sehingga keduanya bisa tumbuh dan berkembang bersama-sama. Beberapa penelitian terdahulu telah meneliti pengaruh kebijakan deviden dan nilai perusahaan (Noorqolby, 2018; Ramadhan, Husnatarina, dan Angela, 2018; Septariani, 2017; Esana dan Darmawan, 2017; Yulenda dan Azib, 2017: dan Senata, 2016). Peneliti terdahulu telah banyak menjukkan temuan adanya pengaruh antara keputusan investasi, keputusan pendanaan, dan kebijakan dividen dengan nilai perusahaan (Nelwan dan 

2017).

\section{TINJAUAN PUSTAKA}

\section{Nilai Perusahaan}

Memaksimalkan kekayaan pemegang saham adalah tujuan dari manajemen keuangan perusahaan, hal ini berarti akan turut serta menaikkan nilai perusahaan dimata publik dalam bentuk standar ukur nilai yang objektif dan berorientasi pada keberlanjutan hidup perusahaan tersebut (Harmono, 2014:1). Pengukuran nilai perusahaan menggunakan harga saham yang menggunakan rasio disebut sebagai rasio penilaian yaitu suatu rasio yang digunakan dalam menilai kinerja saham perusahaan yang diperdagangkan di pasar modal (Sudana, 2011:23).

\section{Keputusan Investasi}

Sugiono (152:2015) menjelaskan bahwa keputusan investasi modal (capital investment decision) merupakan investasi jangka panjang untuk memperoleh keuntungan dimasa mendatang, dimana berkaitan dengan proses perencanaan, penetapan tujuan, pengaturan pendanaan, serta penggunaan kriteria tertentu untuk memilih aktiva jangka panjang. Over atau under investment yang akhirnya akan merugikan perusahaan biasanya disebabkan oleh kesalahan dalam mengadakan peramalan (Sudrajat, 2018:144). Salah satu rasio keputusan investasi yang sering digunakan adalah price earning ratio yaitu membandingkan market price per share (harga pasar pelembar saham) dengan earning per share (laba per lembar saham) (Fahmi (2014:336). Marr (18:2012) menyebutkan, rasio P/E dipakai sebagai acuan analisa saham dengan melihat hubungan antara harga saham dan pendapatan perusahaan. Secara logika jika di telaah lebih lanjut, hal ini merujuk kepada kemampuan sebuah perusahaan dalam menghasilkan laba pada masa yang akan datang, sehingga pihak investor bisa memliki ketertarikan dalam menanamkan modal atau memutuskan memberikan investasi pada suatu perusahaan.

\section{Keputusan Pendanaan}

Keputusan pendanaan adalah sebuah keputusan tentang penetapan sumber dana yang dibutuhkan oleh perusahaan untuk pembiayaan investasi yang dilakukan dan penetapan perimbangan pembelanjaan yang optimum bagi perusahaan (Sudaryo (8:2017).

\section{Keputusan Deviden}

Dividen merupakan salah satu daya tarik utama bagi para pemegang saham. Investor yang memiliki jumlah saham besar dalam sebuah perusahaan sangat menanti-nanti waktu pembagian dividen (Fachrudin, 2013:191). 


\section{Kerangka Pikir}

\section{Gambar 1 Kerangka Pikir Hipotesis}

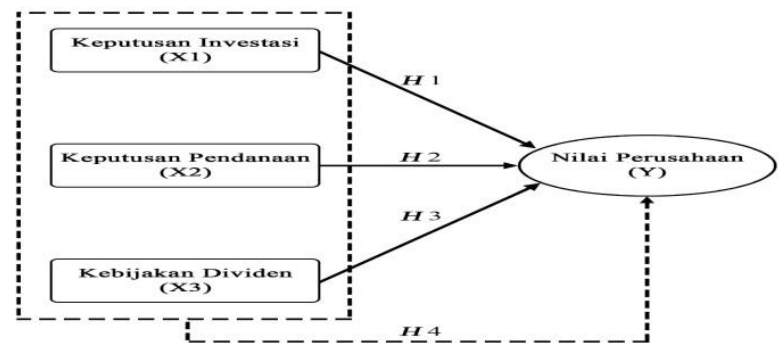

\section{Hipotesis Penelitian}

$\mathrm{H}_{1}=$ Keputusan investasi berpengaruh terhadap nilai perusahaan indeks LQ-45.

$\mathrm{H}_{2}=$ Keputusan pendanaan berpengaruh terhadap nilai perusahaan indeks LQ-45.

$\mathrm{H}_{3}=$ Kebijakan dividen berpengaruh terhadap nilai perusahaan indeks LQ-45.

$\mathrm{H}_{4}=$ Keputusan investasi, keputusan pendanaan, dan kebijakan dividen berpengaruh terhadap nilai perusahaan indeks LQ-45.

\section{METODE PENELITIAN}

Jenis penelitian ini kuantitatif ex post facto dengan menggunakan pendekatan kuantitatif.

\section{Populasi dan Sampel}

225 perusahaan perusahaan indeks LQ-45 yang terdaftar di Bursa Efek Indonesia periode Februari 2017-Februari 2019 dijadikan populasi penelitian. Metode purposive sampling digunakan untuk mendapatkan 29 perusahaan yang memenuhi memenuhi kriteria :

1. Perusahaan berturut-turut masuk dalam indeks LQ 45 periode Februari 2017-Februari 2019.

2. Perusahaan membagikan dividen kepada investor secara teratur.

3. Perusahaan dalam issued history memberikan bonus share.

4. Perusahaan mempunyai data lengkap yang dibutuhkan peneliti.

\section{Pengumpulan Data}

Sumber data pada penelitian ini berupa data sekunder dari perusahaan LQ-45 melalui website Bursa Efek Indonesia www.idx.co.id.

\section{Variabel Operasional}

\section{Nilai Perusahaan}

Rasion Price to Book Value (PBV) dipilih untuk memproksikan nilai perusahaan. Rasio ini membandingkan antara harga saham dengan nilai buku organisasi sebagai sebuah perusahaan yang terus tumbuh (Hery, 2017:6).

\section{Keputusan Investasi}


Keputusan investasi merupakan harapan terhadap hasil keuntungan di masa yang akan datang. Keputusan investasi pada penelitan ini diproksikan menggunakan Price Earning Ratios (PER).

\section{Keputusan Pendanaan}

Debt to Equity Ratio (DER) dipilh untuk memproksikan keputusan pendanaan. Dhameja (2014:114) menjelaskan rasio ini berkaitan dengan utang terhadap ekuitas atau dana pemilik. Ekuitas di sini digunakan dalam arti yang lebih luas sebagai kekayaan bersih (misalkan, modal ditambah laba ditahan), sementara utang biasanya digunakan sebagai pinjaman jangka panjang berbunga.

\section{Kebijakan Deviden}

Kebijakan deviden merupakan salah satu bentuk kompensasi yang di terima oleh pemegang saham, di samping menerima capital gain (Hanafi, 2015:361). Kebijakan deviden dalam penelitian ini diproksikan menggunakan Deviden Payout Ratio (DPR).

\section{Indikator Pengukuran Variabel}

Tabel 1 Indikator Pengukuran Variabel

\begin{tabular}{|c|c|c|}
\hline NO & Variabel & Indikator Pengukuran \\
\hline 1 & Nilai Perusahaan (Y) & $\begin{array}{l}\text { Price to Book Value }(P B V) \\
P B V=\frac{\text { Harga Saham }}{\text { Book Value }} \\
\text { (Sumber: Hery, 2017:6) }\end{array}$ \\
\hline 2 & Keputusan Investasi $\left(\mathrm{X}_{1}\right)$ & $\begin{array}{l}\text { Rumus PER (Price Earning Ratio) } \\
P E R=\frac{M P S(\text { Market Price Per Share })}{E P S(\text { Earning Per Share })} \\
\text { (Sumber: Fahmi, 2014:336) }\end{array}$ \\
\hline 3 & $\begin{array}{l}\text { Keputusan Pendanaan } \\
\left(\mathrm{X}_{2}\right)\end{array}$ & $\begin{array}{l}\text { Rumus DER (Debt Equity Ratio) } \\
\text { DER }=\frac{\text { Total Hutang }}{\text { Total Ekuitas }} \times 100 \% \\
\text { (Sumber: Epstain, 2015:243) }\end{array}$ \\
\hline 4 & Kebijakan Dividen $\left(\mathrm{X}_{3}\right)$ & $\begin{array}{l}\text { Rumus DPR (Dividen Payout Ratio) } \\
D P R=\frac{\text { Dividen Per Share }}{E P S(\text { Earnings Per Share })} \\
\text { (Sumber: Rich, 2014:675) }\end{array}$ \\
\hline
\end{tabular}

\section{Analisis Data}


Teknik analisis regresi linear berganda dengan taraf signifikansi 0,05 untuk menguji pengaruh keputusan investasi, keputusan pendanaan, dan kebijakan dividen terhadap nilai perusahaan indeks LQ-45.

\section{HASIL \& PEMBAHASAN}

Tabel 2 Ringkasan uji Regresi Linier Berganda

\begin{tabular}{|l|c|c|c|c|}
\hline \multicolumn{1}{|c|}{ Variabel } & $\boldsymbol{B}$ & $\mathbf{t}_{\text {hitung }}$ & Sig & Keterangan \\
\hline Konstanta & 0.559 & & & \\
\hline PER & 0.102 & 7.445 & 0.000 & Signifikan \\
\hline DER & -0.023 & -0.925 & 0.358 & Tidaksignifikan \\
\hline DPR & 0.005 & 1.285 & 0.202 & Tidaksignifikan \\
\hline$\alpha$ & $=0.050$ & \\
KoefisienDeterminasi $\left(\mathrm{R}^{2}\right)$ & $=0.454$ & & \\
F-hitung & $=23.329$ & & \\
F-tabel (F $\mathrm{F}_{3,84,0.05)}$ & $=2.713$ & & \\
Signifikansi F & $=0.000$ & & \\
t-tabel (t $\left.\mathrm{t}_{84,0.05}\right)$ & $=1.989$ &
\end{tabular}

Sumber : Data diolah, 2019

\section{Keputusan Investasi Terhadap Nilai Perusahaan}

Pada tabel 2 Hasil statistik uji-t menunjukkan thitung lebih besar dari $t_{\text {tabel }}(7.445>1.989)$ serta nilai sig t $(0.00)<\alpha(0.05)$. Hasil uji ini berarti keputusan yang diambil adalah menolak $\mathrm{H}_{0}$, maka ditarik kesimpulan keputusan investasi (PER) berpengaruh terhadap terhadap nilai perusahaan $(P B V)$. Hal tersebut membuktikan bahwasanya setiap investor yang berinvestasi sudah tentu mempertimbangkan nilai perusahaan tersebut

\section{Gambar 1 Kurva Uji $X_{1}$ terhadap Y}

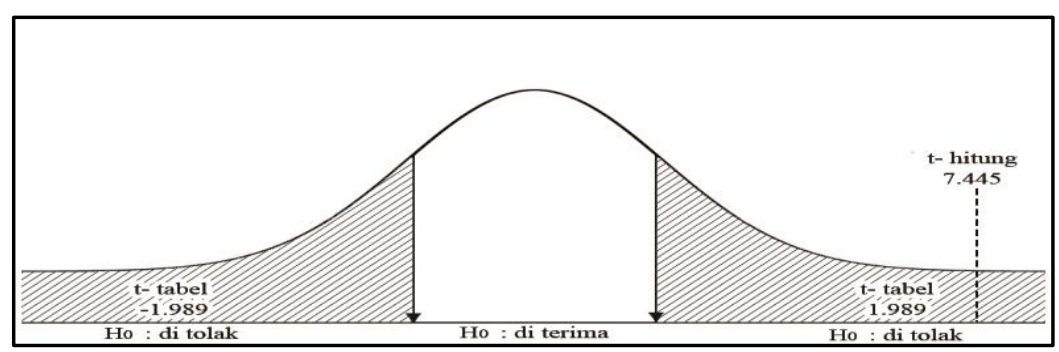

Sumber: Data diolah, 2019

Investor akan tertarik berinvestasi pada perusahaan yang memilik Price Earnings Ratio (PER) yang tinggi. Tingginya permintaan saham memiliki hubungan pada meningkatnya nilai saham perusahaan sehingga secara tidak langsung akan memberikan pengaruh terhadap nilai perusahaan melalui nilai $P B V$ (price book value). Maka keputusan investasi yang dilakukan investor akan memiliki pengaruh positif terhadap nilai perusahaan. 

perusahaan sebagai salah satu jenis informasi yang dikeluarkan oleh perusahaan yang dapat menjadi signal tertentu. Signal informasi yang terkandung dilaporan tahunan perusahaan berupa informasi akuntansi yang sesuai dengan regulator pasar modal. Informasi tersebut pada dasarnya dipeerlukan investor untuk mengevaluasi risiko relative diperusahaan, sehingga investor dapat melakukan diversifikasi portofolio dengan preferensi risiko yang diinginkan. Hasil ini sejalan dengan temuan penelitian Putra (2018) bahwa keputusan investasi yang tinggi dianggap sebagai good news yang bisa merubah persepsi investor ke perusahaan, yang nantinya berpengaruh ke nilai perusahaan.

\section{Keputusan Pendanaan Terhadap Nilai Perusahaan}

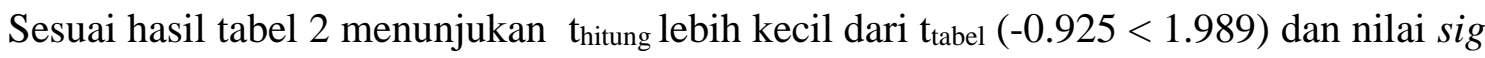
t lebih besar dari $\alpha(0.358>0.050)$. Hasil uji menunjukkan bahwa $\mathrm{H}_{0}$ diterima, maka ditarik kesimpulan keputusan pendanaan (DER) tidak berpengaruh terhadap terhadap nilai perusahaan $(P B V)$. Hasil ini membuktikan bahwa pada uji tersebut hipotesis kedua keputusan pendanaan berpengaruh terhadap nilai perusahaan belum berhasil dicapai.

\section{Gambar 2 Kurva Uji X2 terhadap Y}

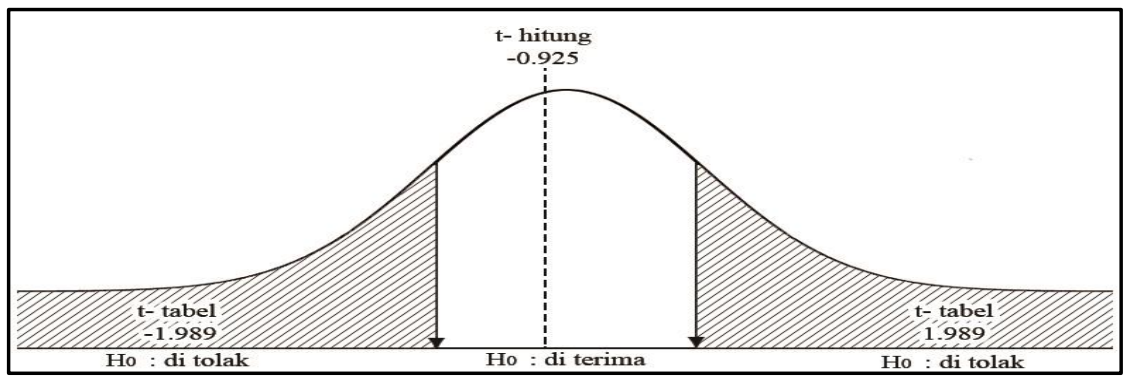

Sumber: Data diolah, 2019

Balancing theories yang merupakan salah satu teori kebijakan pendanaan menjelaskan bahwa perusahaan dalam melakukan kebijakan mencari tambahan dana bisa dengan cara melakukan pinjaman atau menerbitkan obligasi (bonds) (Fahmi, 182:2014). Salah satu resiko dalam teori tersebut menyebutkan bahwa adanya penilaian dari publik dalam kinerja keuangan perusahaan khususnya kemampuan dalam manajemen pengelolaan struktur modal, sehingga adanya permasalahan yang terjadi pada perusahaan bisa menyebabkan menurunnya nilai perusahaan di mata publik. Kebijakan pendanaan bisa sangat menguntungkan terhadap nilai perusahaan, jika pengelolaannya sesuai dengan iklim bisnis yang terjadi maka akan diperoleh manfaat yang besar, namun sebaliknya pada iklim bisnis yang tidak menentu maka manfaat kebijakan pendanaan tidak akan bisa diperoleh dengan baik, sehingga akan mempengaruhi nilai perusahaan itu sendiri. Hasil hipotesis ini sejalan dengan penelitian oleh Ramadhan (2018), Putra (2018), Maulana (2016) dan Suroto (2015) 


\section{Kebijakan Dividen Terhadap Nilai Perusahaan}

Hasil statistika uji-t tabel 2 menunjukan thitung lebih kecil dari tabel $(1.285<1.989)$ dan nilai sig t lebih besar dari $\alpha(0.202>0.050)$. Hasil uji tersebut menunjukkan keputusan bahwa $\mathrm{H}_{0}$ diterima, maka dapat disimpulkan kebijakan dividen (DPR) tidak berpengaruh terhadap nilai perusahaan $(P B V)$. Hasil ini membuktikan hipotesis ketiga kebijakan dividen berpengaruh positif terhadap nilai perusahaan belum berhasil di dicapai.

\section{Gambar 3 Kurva Uji X3 terhadap Y}

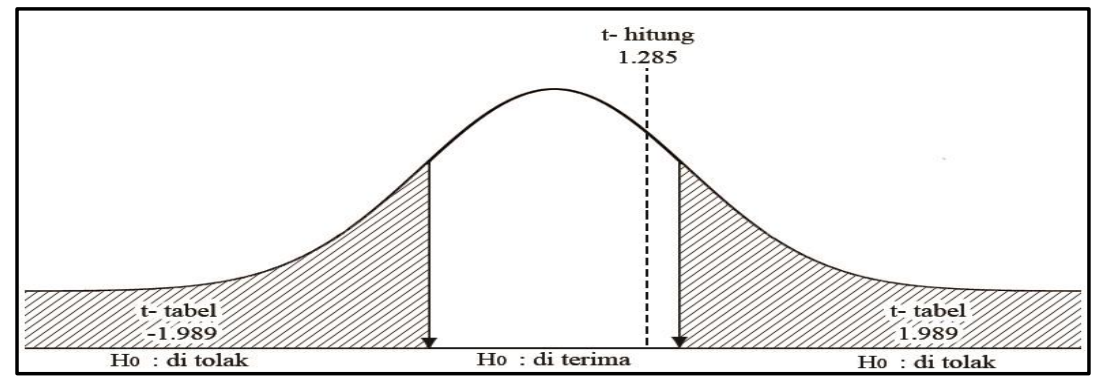

Sumber: Data diolah, 2019

Kebijakan dividen merupakan penentuan tentang berapa besarnya laba perusahaan dalam bentuk dividen yang akan diberikan kepada pemegang saham dan laba yang ditahan perusahaan dalam suatu periode yang akan dibagikan dalam bentuk laba ditahan (Halim, 2015: 135). Investor yang menanamkan modalnya pada suatu perusahaan, pasti menginginkan dan mengaharapkan return atau keuntungan dari investasi yang telah dilakukannya yang berupa dividen dan capital gain. Temuan ini mendukung hasil penelitian sebelumnya oleh Nelwan (2018) dan Ramadhan (2018).

\section{Keputusan Investasi, Keputusan Pendanaan, dan Kebijakan Dividen Terhadap Nilai Perusahaan}

Berdasarkan tabel 2 diperoleh nilai $F_{\text {hitung }}$ lebih besar dari $F_{\text {tabel }}(23.329>2.713)$ dengan signifikansi (0.00) lebih kecil dari $\alpha(0.05)$ sehingga $\mathrm{H}_{0}$ ditolak. Artinya secara bersama-sama variabel bebas yaitu $P E R, D E R$, dan $D P R$ berpengaruh terhadap variabel $P B V$.

\section{SIMPULAN \& SARAN}

\section{Kesimpulan}

1. Terdapat pengaruh keputusan investasi terhadap nilai perusahaan Indeks LQ-45.

2. Tidak terdapat berpengaruh keputusan pendanaan terhadap nilai perusahaan Indeks LQ45.

3. Tidak terdapat berpengaruh kebijakan dividen terhadap nilai perusahaan Indeks LQ-45.

4. Terdapat pengaruh keputusan investasi, keputusan pendanaan, dan kebijakan dividen terhadap Indeks LQ-45. 


\section{Saran}

Peneliti selanjutnya disarankan untuk menambahkan variabel baru dan menambahkan jumlah tahun pengamatan sehingga akan diperoleh sebuah gambaran yang lebih baik tentang kondisi dan perkembangan perusahaan dalam meningkatkan nilai perusahaan.

\section{DAFTAR PUSTAKA}

Alza, R. Z., dan Utama, AA. Gd. S. (2018). Pengaruh Kebijakan Pendanaan, Kebijakan Investasi, dan Kebijakan Dividen Terhadap Nilai Perusahaan dengan Risiko Bisnis Sebagai Variabel Pemoderasi (Studi Empiris pada Perusahaan yang tergabung dalam Indeks LQ45 2011 2015). JRABA (Jurnal Riset Akuntansi dan Bisnis Airlangga). 03: 396-415.

Cahyono, H. S., dan Sulistyawati, A. I. (2016). Keputusan Investasi, Keputusan Pendanaan dan Kebijakan Dividen Sebagai Determinan Nilai Perusahaan. Akusisi:Jurnal Akuntansi. 12: 39-53.

Dhameja, K. (2014). Finance and Accounting for Managerial Competitiveness. New Delhi: S. Chand \& Company.

Epstain, L. (2015). Book Keepping For Dummies. New Jersey: John Wiley \& Sons, Inc.

Esana, R, dan Darmawan, A. (2017). Pengaruh Kebijakan Dividen dan Keputusan Investasi Terhadap Nilai Perusahaan Serta Dampaknya Terhadap Profitabilitas $t+1$ (Studi pada Sub Sektor Industri Barang Konsumsi yang Terdaftar di Bei Periode 20062016). JAB (Jurnal Administrasi Bisnis). 50: 201-210.

Fahmi, I. (2014). Analisa Kinerja Keuangan. Bandung: Alfabeta.

Fakhrudin, H. M. (2008). Go Public: Strategi Pendanaan dan Peningkatan Nilai Perusahaan. Jakarta: PT Elex Media Komputindo.

Halim, A. (2015). Manajemen Keuangan Bisnis: Konsep dan Aplikasinya. Jakarta: Mitra Wacana Media.

Hanafi, M. M. (2015). Manajemen Keuangan. Yogyakarta: BPFE.

Hantono. (2018). Konsep Analisa Laporan Keuangan dengan Pendekatan Rasio dan SPSS. Yogyakarta: Deepublish.

Harmono. (2014). Manajemen Keuangan Berbasis Balanced Scorecard, Pendekatan Teori, Kasus dan Riset Bisnis. Jakarta: Bumi Aksara.

Hery. (2017). Kajian Riset Akuntansi: Mengulas Berbagai Hasil Penelitian Terkini dalam Bidang Akuntansi dan Keuangan . Jakarta: Grasindo.

Marr, B. (2012). Key Performance Indicator (KPI): The 75 Measures Every Manager Needs to Know. Hariow, United Kingdom: Pearson Education Limited.

Maulana., Rifki. M., Hermanto., dan Nugraha, I. N. (2016). Pengaruh Keputusan Investasi, Keputusan Pendanaan Dan Kebijakan Dividen Terhadap Nilai Perusahaan Pada Perusahaan Lq 45 Di Bursa Efek Indonesia Tahun 2011-2015. Jurnal Distribusi: Jurnal Ilmu Manajemen dan Bisnis. 04: 29-50.

Muharti dan Anita, R. (2017). Pengaruh Keputusan Investasi, Pendanaan, Kebijakan Deviden Terhadap Nilai Perusahaan (Studi Pada Perusahaan Sektor Property dan Real Estate Di Bursa Efek Indonesia Periode 2011-2014). Jurnal Ilmiah Ekonomi dan Bisnis. 14: 142-155.

Nelwan, Andreas, dan Tulung, J. E. (2018). Pengaruh Kebijakan Dividen, Keputusan Pendanaan dan Keputusan Investasi Terhadap Nilai Perusahaan pada Saham Bluechip 
yang Terdaftar di Bei. Jurnal Emba (Ekonomi, Manajemen, Bisnis dan Akuntansi). 06: $2878-2887$.

Nurqoolby, B. (2018). Pengaruh Struktur Modal dan Kebijakan Dividen Terhadap Nilai Perusahaan pada Perusahaan di LQ45 Periode 2012-2015. JURISMA (Jurnal Riset Bisnis dan Manajemen). 03: 83-94.

Putra,. Darma, S., Hidayati, N., dan Junaidi. (2018). Keputusan Investasi Keputusan Pendanaan dan Kebijakan Dividen Terhadap Nilai Perusahaan (Studi Kasus Perusahaan LQ45 yang Terdaftar di Bursa Efek Indonesia). E-JRA. 07: 73-84.

Ramadhan., Fajar, G., Husnatarina, F., dan Angela, L. M. (2018). Pengaruh Kebijakan Hutang dan Kebijakan Dividen Terhadap Nilai Perusahaan Kelompok LQ 45 yang Terdaftar di Bursa Efek Indonesia Tahun 2012-2016. Jurnal RAK (Riset Akuntansi Keuangan). 03: 65-73.

Rich., Jay S., Jones, J. P., dan Mowen, M. M. (2014). Cornerstone of Financial Accounting. 3rd Ed. South-Western: Cengage Learning.

Santoso, S. (2018). Mengusai Statistik dengan SPSS 25. Jakarta: PT Elex Media Komputindo.

Senata, M. (2016). Pengaruh Kebijakan Dividen Terhadap Nilai Perusahaan Yang Tercatat Pada Indeks LQ-45 Bursa Efek Indonesia. Jurnal Wira Ekonomi Mikroskil. 6: 73.

Septariani, D. (2017). Pengaruh Kebijakan Dividen dan Kebijakan Hutang Terhadap Nilai Perusahaan (Studi Empiris pada Perusahaan LQ45 di Bei Periode 20122015). Journal Of Applied Business And Economics. 03: 183-195.

Sudana, I. M. (2011). Manajemen Keuangan Perusahaan dan Praktik. Surabaya: Erlangga.

Sudaryo., Yoyo., Sjarif, D., dan Sofiati N. A. (2017). Keuangan di Era Otonomi

Daerah. Yogyakarta: CV Andi Offset.

Sudrajat, Usep, dan Suwaji. (2018). Ekonomi Manajerial. Yogyakarta: Deepublish.

Sugiyono. (2017). Metode Penelitian Kuantitatif, Kualitatif dan R\&D. Vol. Ke-25.

Bandung: CV. Alfabeta.

Sugiyono, A. (2015). Akuntansi Informasi dalam Pengambilan Keputusan. Jakarta:

Gramedia.

Suroto. (2015). Pengaruh Keputusan Investasi, Keputusan Pendanaan dan Kebijakan Dividen Terhadap Nilai Perusahaan (Studi Empiris pada Perusahaan Lq-45 yang Terdaftar di Bursa Efek Indonesia Periode Februari 2010-Januari 2015). Serat Acitya: Jurnal Ilmiah Untag Semarang. 04: 100-117.

Yulenda, Tria, Tandika, D., dan Azib. (2017). Pengaruh Profitabilitas Dan Kebijakan Dividen Terhadap Nilai Perusahaan (Studi Kasus Pada Perusahaan LQ45 Yang Terdaftar Di Bursa Efek Indonesia (BEI) Periode 2011-2015). Prosiding Manajemen. 3: 27-32. 